\title{
Phosphorus Recovery from Carbonized Sewage Sludge by Hydrothermal Processes Using Potassium Hydroxide
}

\author{
Masaaki Takahashi $^{1 *}$,Yukimasa Takemoto ${ }^{1}$, Ken Oonishi $^{2}$ and Eiji Yuuki ${ }^{2}$ \\ 1. Yokkaichi University, Research Laboratory on Environmental Technology, Kayoutyou1200, Yokkaichi, Mie, 512-8512, Japan \\ 2. Mie Chuo Kaihatsu Co., Ltd, Hachiya4713, Yono, Iga, Mie, 518-1152, Japan
}

\begin{abstract}
Sewage sludge contains significant amounts of phosphorus, and in order to establish the phosphorus recovery, an investigation of phosphorus recovery from carbonized sewage sludge was investigated. Carbonized sewage sludge was mixed with a potassium hydroxide aqueous solution and treated in hydrothermal conditions for 2 hours. After this treatment, hot-water was added to the treated mixture and phosphorus containing extract was recovered. Phosphorus was recovered as a form of potassium phosphate from phosphorus containing extract. Optimal recovery conditions were investigated in treatment temperature, and recovered phosphorus was confirmed as potassium phosphate by X-ray analysis, and its recovery rate was estimated to be about $76-77 \%$.
\end{abstract}

Key words: Carbonized sewage sludge, hydro-thermal treatment, phosphorus recovery, potassium.

\section{Introduction}

The amount of the sewage sludge is increasing due to the wide introduction of sewage systems, and most of the sewage sludge has been disposed in a landfill site as a waste. Sewage sludge contains significant amounts of phosphorus, however, recovery technology has not been well developed, and a lot of phosphorus in the sludge is not recycled, and this important element is discharged into the environment without utilization. In order to establish the phosphorus recovery technology from sewage sludge, many studies of the chemical processes [1-5] are under way.

Charcoal has many usages as a fuel, adsorbent, and other industrial materials, and one of the recycle methods, carbonization techniques [6] has been introduced. However, charcoal made from sludge has limited utilization because of high ash content, especially phosphorus component. Phosphorus removal has some advantage for recovery of phosphorus and charcoal of low ash content.

*Corresponding author: Masaaki Takahashi, researcher, research field: environmental technology.
Phosphorus removal, some alkali-extraction methods [7] have been investigated, and hydrothermal processes [8] are considered useful compared to conventional alkali extraction. The hydrothermal processes are considered to be based on the reaction shown in Eq. (1):

$$
\begin{aligned}
& \text { Sewagesludge }\left(\mathrm{SiO}_{2}, \mathrm{AlPO}_{4}\right)+\mathrm{nMOH}+\mathrm{zH}_{2} \mathrm{O} \rightarrow \\
& \mathrm{M}_{2} \mathrm{O} \cdot \mathrm{xAl}_{2} \mathrm{O}_{3} \cdot \mathrm{ySiO}_{2} \cdot \mathrm{zH}_{2} \mathrm{O}+\mathrm{M}_{3} \mathrm{PO}_{4}
\end{aligned}
$$

where, $\mathrm{M}$ is alkali metal.

In this method, the charcoal is mixed with aq. solution of alkali metal hydroxide (like $\mathrm{NaOH}$ or $\mathrm{KOH}$ ), and treated at $70{ }^{\circ} \mathrm{C}$ to $160{ }^{\circ} \mathrm{C}$. After 2 or 6 hours of heating, phosphorus is extracted by addition of the hot water to the treated mixture.

Treated charcoal is separated by filtration, and extracted phosphorus (expected to be alkali metal phosphate) can be recovered by crystallization followed by vaporization of the filtrate (as shown in Fig. 1). $\mathrm{Na}_{3} \mathrm{PO}_{4}$ was recovered by this method using $\mathrm{NaOH}$ as mentioned in previous report [9].

Potassium and phosphorus are one of the inevitable elements of plants [10], and recovery from sewage 


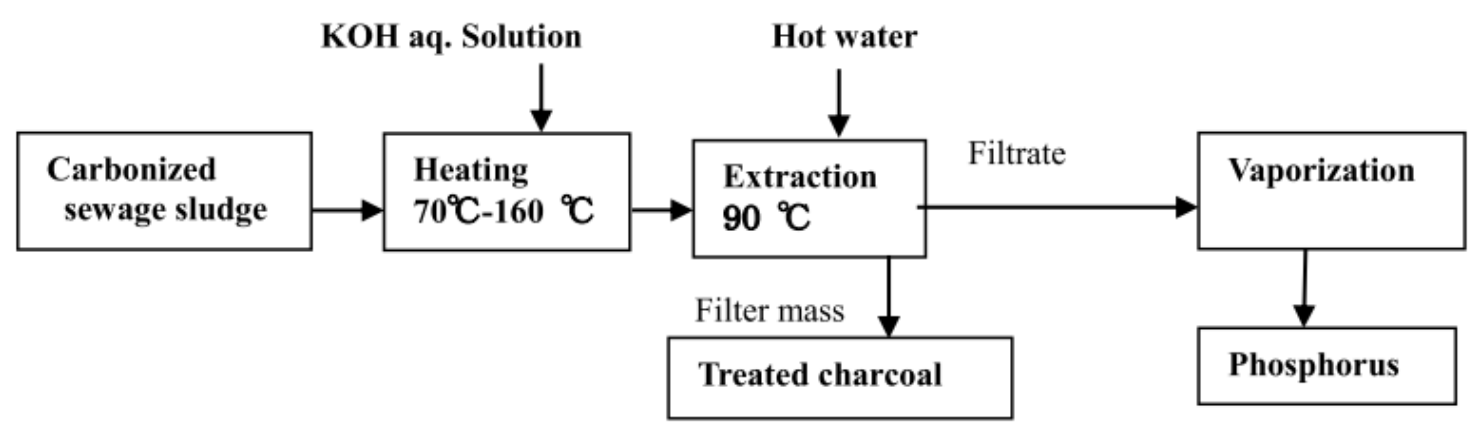

Fig.1 Phosphorus recovery method.

sludge is regarded important matter. We investigated a recovery method of $\mathrm{K}_{3} \mathrm{PO}_{4}$ using $\mathrm{KOH}$ and found the optimal recovery conditions.

\section{Method}

\subsection{Raw Material and Extracting Apparatus}

The experiments were carried out using the charcoal of sewage sludge which was made from sewage sludge by carbonization in an anaerobic chamber at $700{ }^{\circ} \mathrm{C}$.

The reactor vessel (capacity: $300 \mathrm{~mL}$ ) is made of steel with a small hole in the cap shown in previous report [11]. The charcoal was mixed with aq. solution of potassium hydroxide and put into the reactor vessel, heated in the heating chamber. After treatment, treated charcoal was transferred into the extracting vessel (1,000 mL), phosphorus was extracted by addition of hot water.

\subsection{Phosphorus Recovery Condition}

The optimal phosphorus recovery conditions are considered from the previous report [12], as mixing ratio (v/v); 1:1, alkali addition rate; $30 \mathrm{~g} \mathrm{KOH/50} \mathrm{g}$ charcoal and heating time 2 hours to 6 hours.

In order to find an optimal heating temperature, $10 \mathrm{~g}$ of charcoal was mixed with aq. solution of $\mathrm{KOH} \mathrm{(6} \mathrm{g}$ in $10 \mathrm{~mL}$ of water), and heated in some treating temperature (up to $160^{\circ} \mathrm{C}$ ), in the condition (mixing ratio, alkali addition rate as mentioned before). Phosphorus concentration in the filtrate was analyzed by chemical analysis, and high phosphorus extraction rate was found in a temperature around $95{ }^{\circ} \mathrm{C}$ to 160 ${ }^{\circ} \mathrm{C}$ (shown in Fig. 2). From these results, optimal phosphorus recovery conditions are decided as shown in Table 1.

\section{Result and Discussion}

\subsection{Feature of the Recovered Materials}

In order to confirm the feature of the recovered phosphorus, $50 \mathrm{~g}$ of charcoal was mixed with aq. solution of $\mathrm{KOH}\left(\mathrm{KOH}: 30 \mathrm{~g}+\mathrm{H}_{2} \mathrm{O}: 50 \mathrm{~mL}\right.$ ), and heated at $120{ }^{\circ} \mathrm{C}, 2$ hours later, transferred into the vessel, extraction was carried out by addition of 500 $\mathrm{mL}$ of hot water, and maintained at $90{ }^{\circ} \mathrm{C}$ in 10 minute, later, filtrate (filtrate-1) was recovered using filter paper (No2, ADVANTEC, Toyo Roshi Kaisha, Ltd.). The filter mass was added $500 \mathrm{~mL}$ of hot water, and heated at $90{ }^{\circ} \mathrm{C}$ in 10 minute, and filtrate- 2 was also

Table 1 Optimal recovery condition.

\begin{tabular}{|l|l|}
\hline Mixing rate & $\mathrm{s} / \mathrm{L}=1: 1$ \\
\hline KOH addition rate & KOH 6 g in $10 \mathrm{~g}$ of charcoal \\
\hline Treatment temperature & $120^{\circ} \mathrm{C}$ \\
\hline Heating time & 2 hours to 6 hours \\
\hline
\end{tabular}

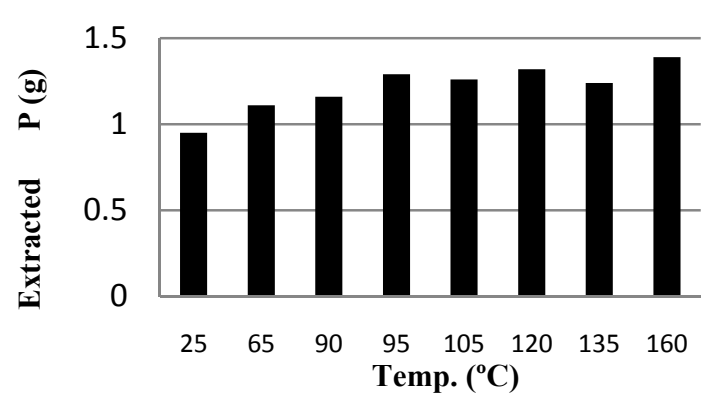

Fig. 2 Extracted phosphorus amount to treatment temperature (Charcoal: $10 \mathrm{~g}$, NaOH $6 \mathrm{~g}$, Heating time: $2 \mathrm{~h}$ ). 
recovered like before. The filter mass was dried at 105 ${ }^{\circ} \mathrm{C}$, and $42 \mathrm{~g}$ - $44 \mathrm{~g}$ of treated charcoal was recovered.

The phosphorus in the filtrate was expected to be a form of $\mathrm{K}_{3} \mathrm{PO}_{4}$, which had very high solubility in water, and also contains non-reacted $\mathrm{KOH}$, therefore, direct dehydration was considered difficult. In order to investigate the composition of the recovered phosphorus, non-reacted $\mathrm{KOH}$ was converted to $\mathrm{KCl}$ by neutralization. $35 \mathrm{~g}$ of $\mathrm{HCl}$ (Wako Chemicals Co. Ltd, assay 35\%) was added to the filtrate (filtrate-1 + filtrate-2, total $1,000 \mathrm{~mL}$ ) , and adjusted to $\mathrm{pH} 4.0$, and dried by evaporation at $105{ }^{\circ} \mathrm{C}$, and $45 \mathrm{~g}$ of phosphorus was recovered. The recovered phosphorus contains $\mathrm{KCl}$ which was formed by neutralization, and substantial amount of the phosphorus (as a form of $\mathrm{NaH}_{2} \mathrm{PO}_{4}$ ) was estimated $22 \mathrm{~g}$ by chemical mass balance.

The treated charcoal was incinerated at $600{ }^{\circ} \mathrm{C}$ for analysis. Incinerated ash and recovered phosphorus were analyzed using XRF (Rigaku Corporation. SPECTRO XEPOS).The appearance of the treated charcoal is black grain, and no-apparent change in its features was found and ash content was almost same compared to non-treated charcoal as shown in Table 2.

The ash of the treated charcoal was mainly composed of $\mathrm{SiO}_{2}, \mathrm{Al}_{2} \mathrm{O}_{3}, \mathrm{Fe}_{2} \mathrm{O}_{3}, \mathrm{CaO}$ and $\mathrm{K}_{2} \mathrm{O}$ as shown in Fig. 3. The amount of the phosphorus in the treated charcoal was decreased by the phosphorus removal. However, small amounts of non-reacted $\mathrm{P}_{2} \mathrm{O}_{5}$ remained in the treated charcoal, and $\mathrm{SiO}_{2}, \mathrm{CaO}$ and $\mathrm{Fe}_{2} \mathrm{O}_{3}$ component in the charcoal were relatively increased by the treatment because of elution of the phosphorus. $\mathrm{K}_{2} \mathrm{O}$ content in the treated charcoal has increased. $\mathrm{K}_{2} \mathrm{O}$ is considered to be remained with residue water in the charcoal or any reaction of $\mathrm{KOH}$ and ash components of the charcoal. The recovered phosphorus is mainly composed of $\mathrm{K}_{2} \mathrm{O}$ and $\mathrm{P}_{2} \mathrm{O}_{5}, \mathrm{Cl}$ and a small amount of $\mathrm{Na}_{2} \mathrm{O}$ and $\mathrm{Al}_{2} \mathrm{O}_{3} . \mathrm{KCl}, \mathrm{KH}_{2} \mathrm{PO}_{4}$, and compound of $\mathrm{Al}$ and $\mathrm{P}$ was found by $\mathrm{X}$-ray diffraction (Rigaku Corporation) as shown in Fig 4. $\mathrm{KCl}$ was considered as a by-product of neutralization, $\mathrm{KH}_{2} \mathrm{PO}_{4}$ was also considered to be formed by neutralization (conditional change: strong alkali to $\mathrm{pH}$ = 4) [13]. Al component in the recovered phosphorus was considered to be non-reacted phosphorus which was directly extracted from charcoal as a form of $\mathrm{AlPO}_{4}$. From these results, recovered phosphorus was considered mainly composed of potassium phosphate $\left(\mathrm{K}_{3} \mathrm{PO}_{4}\right)$ from this chemical composition and extracted condition (in high alkali condition: $\mathrm{pH}>13$ ).

\subsection{Phosphorus Recovery Rate}

The phosphorus recovery rate was calculated as Eq. (2).

Table 2 Amount of recovered material.

\begin{tabular}{lllll}
\hline & Raw charcoal (A) & KOH & Treated charcoal & Recovered phosphorus \\
\hline Amount & $50 \mathrm{~g}$ & $30 \mathrm{~g}$ & $43 \mathrm{~g}$ & $45 \mathrm{~g}$ \\
Ash content & $59-60 \%$ & - & $58-60 \%$ & - \\
\hline
\end{tabular}

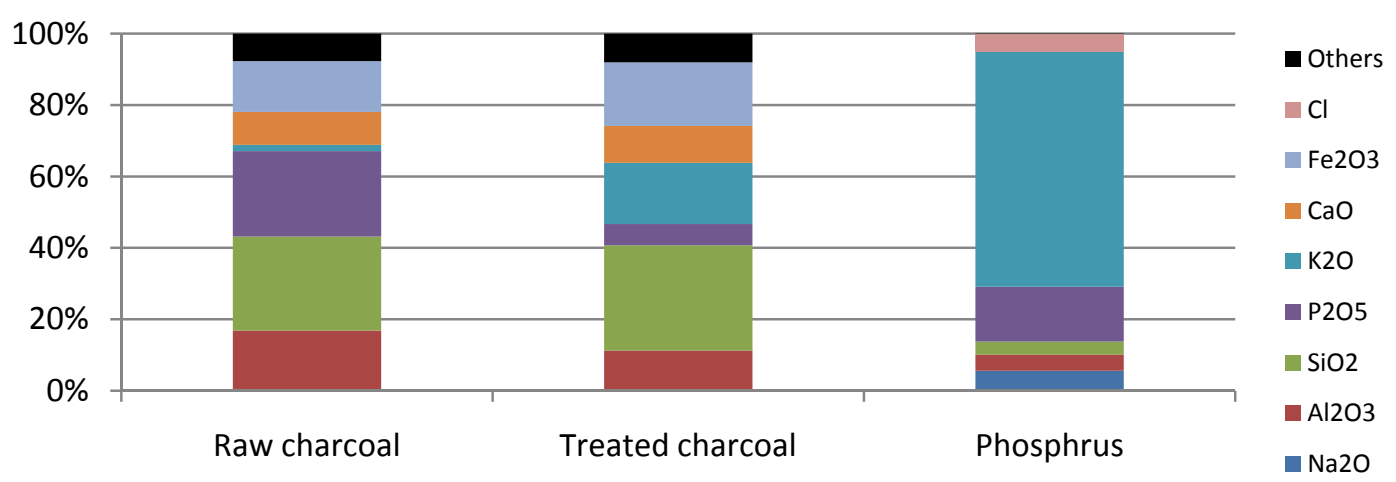

Fig. 3 Composition of the recovered materials (content of the ash component). 


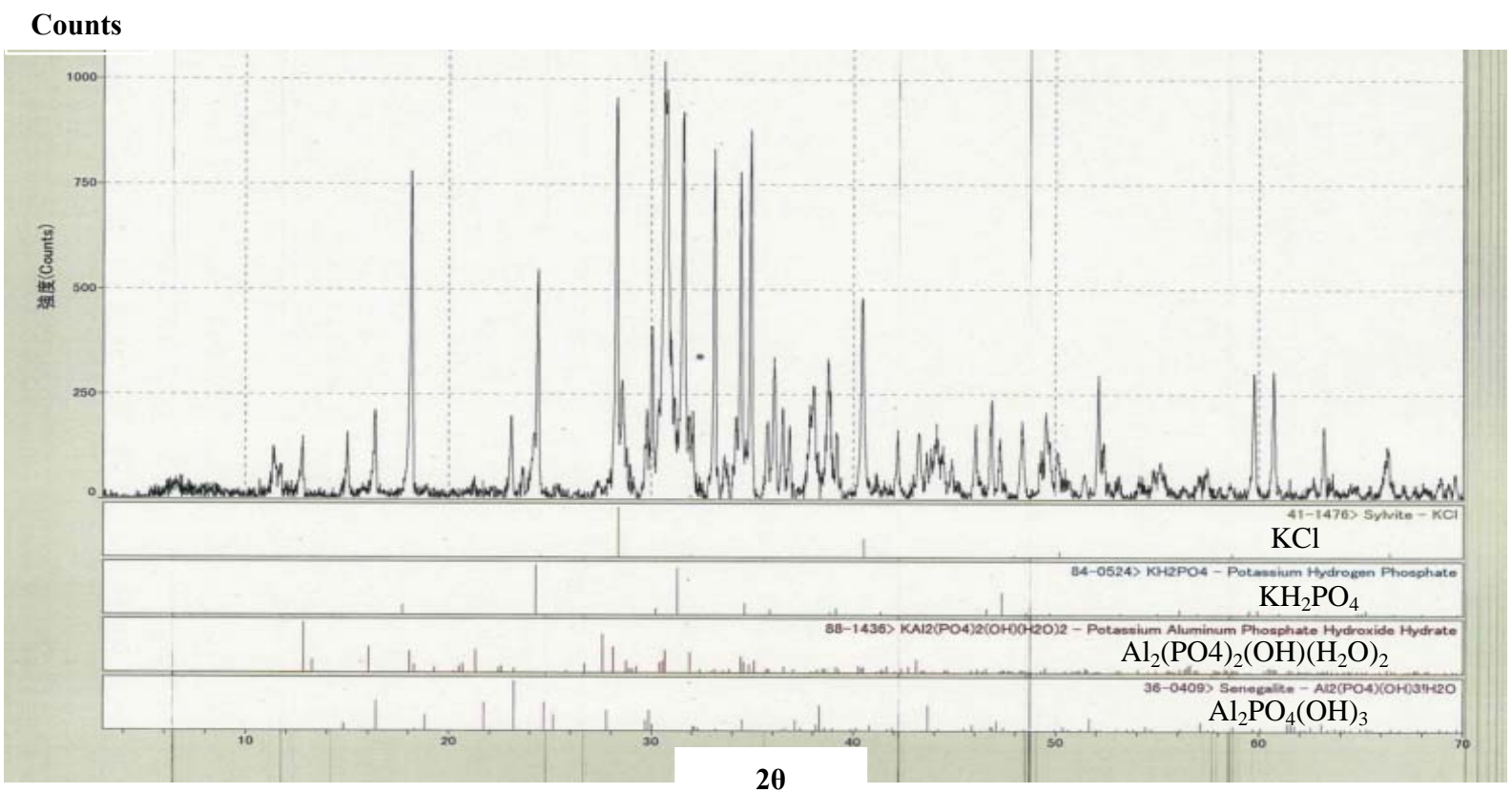

Fig. 4 XRD of the recovered phosphorus.

$\mathrm{P}(\%)=(\mathrm{P} 1 \times \mathrm{A} 1-\mathrm{P} 2 \times \mathrm{A} 2) \div \mathrm{P} 1 \times \mathrm{A} 1 \times 100$

where, A1 (\%) was ash content of the non-treated charcoal, A2 (\%) was ash content of the treated charcoal, P1 (P: mg/ash: g) is phosphorus content in the non-treated charcoal and P2 (P: mg/ash: g) was phosphorus content in the treated charcoal.

Phosphorus recovery rate was estimated to be $76 \%$ to $77 \%$, which was higher compared by the result that carried out using $\mathrm{NaOH}$ [14].

\section{Conclusions}

In order to find a method of phosphorus recovery from charcoal, hydro-thermal method using $\mathrm{KOH}$ was investigated. Phosphorus was successfully recovered as potassium phosphate from the charcoal of sewage sludge by this treatment, and its optimal recovery condition was investigated, and the recovery rate was estimated to be $76-77 \%$. The treated charcoal of this method has lower concentrations of phosphorus and is regarded more useful compared to a non-treated one because of its lower phosphorus concentration. Phosphorus was recovered as a form of $\mathrm{K}_{3} \mathrm{PO}_{4}$ by this method, which is regarded good for fertilizer, however, further investigations are needed to attain a higher recovery rate and practical methods for utilization

\section{Reference}

[1] Okano, K., Umemoto, M., Kagami, J., Honda, K., Ohtake, H. and Miura, K. et al. 2013. "Novel Technique for Phosphorus Recovery from Aqueous Solutions Using Amorphous Calcium Silicate Hydrates (A-CSHs).” Water Research 47 (7): 2251-9.

[2] Nakahara, K. 2001. "Vitrification Process for Recovery of Phosphorus/Phosphoric Acid from Sewage Sludge Ash.” Industrial Water 514: 2-10 (in Japanese).

[3] Nakahara, K. 2003. "Verification Process for Recovery of Phosphorus from Sewage Sludge.” Resources Prosing 50 (2): 68-73 (in Japanese).

[4] Sonoda, K., Tokukura, K., Mori, T., Komazawa, I. and Wada, T. "Phosphoric Acid Recovering from Incinerated Ashes of Sewage Treatment Sludge." In Proceedings of the $7^{\text {th }}$ Annual Conference of the Japan Society of Waste Management Expert (in Japanese).

[5] Takahashi, M., Kato, S., Shima, H., Sarai, E., Ichioka, T. and Hayakawa, S. et al. 2001. "Technology for Recovering Phosphorus from Incinerated Wastewater Treatment Sludge.”Chemosphere 44: 23-9.

[6] Hinata, H., Uchino, K., Yasui, T. and Saito, T. 1996. "Utilization of Sewage Sludge as form of Active Carbon." In Proceedings of the $7^{\text {th }}$ Annual Conference of the Japan Society of Waste Management Expert. 6-16: 288-90 (in Japanese). 
[7] Yoshida, K., Takahashi, Y. and Hatano, M. 2001. "The Experiment on the Recovering of Sodium Phosphate from Incinerated Ash of Sewage Sludge.” In Proceedings of the $12^{\text {th }}$ Annual Conference of the Japan Society of Waste Management Experts. 280-282 (in Japanese)

[8] Sato, K., Takahashi, M., Onari, Y., Kato, S. and Enjyoji, H. 2004. "A Technique for Recovering Sodium Phosphate from Sewage Treatment Sludge by Hydrothermal Synthesis." Transactions of Materials Research Society of Japan 29 (5): 2021-4.

[9] Takahashi, M., Sato, K., Kato, S. and Enjyoji, H. 2007. "Technique for Recovering Phosphorus from Sewage Sludge." In Proceedings of the $8^{\text {th }}$ International Conference on Ecomaterials (ICEM8). 2: 389-95.

[10] Nihon Kaki Garden Center. 2016. Nihon Kaki Garden Center."ShouhinnIchiran (Commodity List). Accessed Apr. 14, 2016. http://www.denningfourcade.com/category/01-03.php.

[11] Takahashi, M., Takemoto, Y. and Oonishi, K. 2013. "Phosphorus Recovery from Charcoal of Sewage Sludge Using NaOH.” International Journal for Sustainable Innovations 3 (1): 37-44.

[12] Takahashi, M. and Takemoto, Y. 2009. "Phosphorus Recovering from Carbonized Sewage Sludge Using Hydrothermal Processes.” In Proceedings of $20^{\text {th }}$ Annual Conference of Japanese Society of Material Cycles and Waste Management. C2-2: 323-34 (in Japanese).

[13] Kanto Chemical Co., INC. Topics: Accessed Apr. 14, 2016.

http://www.kanto.co.jp/products/shokuhin/tenkabutu/rins anen/rinsanen.html.

[14] Takahashi, M., Takemoto, Y. and Onishi, K. 2015 "Phosphorus Recovery from Carbonized Sewage Sludge by Hydrothermal Processes.” Journal of Material Science and Engineering B 5 (1-2): 58-62. 